\title{
CHANGES IN THE PHYSICOCHEMICAL AND MICROBIAL QUALITY OF WASTEWATER FROM A WASTEWATER TREATMENT PLANT
}

\author{
Omotayo, A.E. ${ }^{1 *}$, Eboreime, P.I. ${ }^{1}$, Aina, A.T. ${ }^{2}$ and Simeon, O.M. ${ }^{1}$ \\ ${ }^{1}$ Department of Microbiology, University of Lagos, Lagos, Nigeria \\ ${ }^{2}$ Works and Physical Planning Department, University of Lagos, Lagos, Nigeria \\ E-mail: elizabethomotayo@yahoo.com, preciouseboreime@yahoo.com, ainaadetinuke@gmail.com, \\ simeon_oladapo@yahoo.com
}

Corresponding Author: Omotayo A. E. Phone: +2348033723181 Email: elizabethomotayo@yahoo.com (Received: $6^{\text {th }}$ March 2017; Accepted: $9^{\text {th }}$ September, 2017)

\section{ABSTRACT}

\begin{abstract}
The discharge of wastewater directly into the environment could constitute serious health hazards to humans and other life forms. This study aimed at determining the changes in the physicochemical and bacteriological quality of wastewater from a treatment process plant. Wastewater samples were aseptically collected at 10 different points of a treatment plant and bacterial isolates were obtained from them. Isolates were identified using biochemical technique and API 20E identification system. The isolates were assessed for resistance to common antibiotics using Kirby-Bauer disk diffusion method from which the Multiple Antibiotic Resistance (MAR) Index was calculated. There was improvement in the physicochemical parameters analyzed. The biological oxygen demand, dissolved oxygen, $\mathrm{pH}$, temperature, turbidity, salinity, sulphate and heavy metal concentrations were within acceptable wastewater effluent limits at point of discharge. The total heterotrophic bacterial population, total coliforms and total heterotrophic fungi ranged from $1.4 \times 10^{7}$ to $4.0 \times 10^{2}, 3.2 \times 10^{4}$ to $2.0 \times 10^{2}$ and $5.6 \times 10^{4}$ to $2.5 \times 10^{2} \mathrm{cfu} \mathrm{ml}^{-1}$ at the point of entry and discharge to the environment respectively. Thirteen bacterial species were detected from the wastewater samples collected which include Enterobacter species (3), Escherichia spp. (3), Klebsiella species (3), Enteric group 69 (1), Rahnella aquatilis (1), Edwardsiella tarda (1) and Buttiauxella ferraguitiae (1). None of the isolates had 100\% susceptibility to the antibiotics investigated. The most prevalent multiple antibiotic resistance phenotype observed among the isolates were tetracycline, gentamicin and cotrimoxazole. The MAR values ranged from 0.16 to 0.83 . The result proved that the treatment process was effective in reducing the final concentrations of the physicochemical parameters, microbial load and pathogen discharged into the environment.
\end{abstract}

Keywords: Antibiotics, coliforms, metals, physicochemical, wastewater.

\section{INTRODUCTION}

One of the most critical problems of developing countries is the improper management of vast amount of waste generated by various anthropogenic activities and its unsafe disposal into the environment (Fakayode, 2005). Wastewater also referred to as sewage is a combination of either dissolved or suspended matter of one or more of domestic effluent, water from commercial establishments and institutions, industrial effluent, storm water and other urban run-off, agricultural, horticultural and aquaculture effluent (Adeniran et al., 2012; Olutiola, 2010; Raschid-Sally and Jayakody, 2008). Wastewater is essentially the water supply of the community after it has been fouled by a variety of uses (Zhou and Smith, 2002). As a result, water bodies which are major receptacles of treated, untreated or partially treated industrial wastes have become highly polluted. The resultant effects of this on public health and the environment are usually great in magnitude (Osibanjo et al., 2011). However, the same sewage if properly treated can again serve for drinking and the many other uses of everyday living.

Waste treatment practice is based on physical, chemical and biological operations aimed to eliminate and/or render inert, constituents considered pollutants and dangerous to public and environmental health (Burkhardt et al., 2000). Conventional wastewater treatment plants configuration consists of preliminary screening and other mechanical technique (i.e. pretreatment), followed by sedimentation of settle-able matter (i.e., clarification or treatment) and further removal of nutrients by enhancement of microbiological activity by aeration followed by clarification (i.e. activated sludge or secondary treatment) (Burkhardt et al., 2000; Lens et al., 2001). In a review by Chen et al. (2017), numerous studies indicated that influent composition, 
process configuration, operating parameters and environment conditions are the main driving factors for microbial community structure changes in wastewater treatment systems. Depending on wastewater initial quality and final effluent destination, additional treatment (i.e. disinfection, tertiary and advanced) are applied to remove remaining suspended and dissolved materials (i.e. metals, synthetic organics, microbes) and achieve certain quality level (Asano and Levin, 1996). According to Badejo et al. (2011), domestic wastewater disposal into near-by rivers and streams in Nigeria, is a common phenomenon. Akpata and Ekundayo (1998) reported that 4.6 million people died from diarrhea and a sizeable number of casualties were experienced from ascariasis, guinea worm and trachoma due to deterioration of the water quality.

The occurrence and spread of antibiotic-resistant bacteria are pressing public health problems worldwide. Wastewater may represent significant reservoir for these organisms which could be disseminated in the environment. Therefore, the aim of this study was to assess the effectiveness of a wastewater treatment plant in the improvement of the physicochemical attributes and microbial quality of the discharged effluent.

\section{MATERIALS AND METHODS}

\section{Sample Source}

Water samples were collected from ten treatment points along a wastewater treatment plant used in the study of Adeniran et al. (2012) in Lagos, Nigeria between the hours of 8 and $9 \mathrm{am}$. The samples were collected in clean 2 liter containers each and labeled A-J with A as the influent, $\mathrm{J}$ as the final effluent and the others serially arranged in between. The samples were immediately transferred to the laboratory for analysis.

\section{Physicochemical Analysis}

The physicochemical parameters were carried out as described by Ademoroti (1996). These include, biological oxygen demand (BOD), dissolved oxygen (DO), $\mathrm{pH}$, temperature, turbidity, salinity, sulphate, phosphate, ammonia and appearance. Heavy metals (cadmium, copper, iron, lead, zinc, chromium, cobalt, nickel and silver) concentrations were determined using the Atomic Absorption Spectro-photometer (AAS). Metal concentration in the test water was recorded in $\mathrm{mg}$ $1^{-1}$ (APHA, 1985).

\section{Microbiological Analysis \\ Total Heterotrophic Bacterial Population}

The total heterotrophic bacterial count was carried out on nutrient agar plate. Serial dilution of the water samples was carried out and aliquots of $0.1 \mathrm{ml}$ were plated on solidified-dried medium. Seeded plates were incubated upside down for 48 hours at $37{ }^{\circ} \mathrm{C}$ and plates with distinct colonies greater than 30 and less than 300 were counted and recorded as $\mathrm{cfu} / \mathrm{ml}$.

\section{Coliform Count}

Total coliform count was estimated by the Most Probable Number (MPN) technique using MacConkey (MAC) broth. Faecal coliforms were estimated using Eosin Methylene Blue (EMB) Agar prepared according to manufacturer's instructions. Seeded plates were incubated at $37^{\circ} \mathrm{C}$ and $44{ }^{\circ} \mathrm{C}$ for about $48 \mathrm{~h}$ for coliforms and faecal coliforms respectively. The 5- tube (MPN) technique as described by Collee et al. (1989) was used to determine the total coliform counts. The result was interpreted using the five tubes MPN table and recorded as MPN/100 ml.

\section{Bacterial Identification Test}

The bacterial colonies obtained on MacConkey and EMB Agar were Gram-stained and identified using the Analytical Profile Index (API) kit $20 \mathrm{E}$ and species were confirmed using ABIS ONLINE (www.tgw1916.net/bacteria _logare.html) software.

\section{Antibiotics Sensitivity Test}

The antibiotics sensitivity test was carried out using Kirby-Bauer disk diffusion method on Muller-Hinton agar. The ABTEK negative sensitivity disc (gentamicin, $10 \mu \mathrm{g}$; nalidixic acid, $30 \mu \mathrm{g}$; streptomycin, $10 \mu \mathrm{g}$; tetracycline, $30 \mu \mathrm{g}$; cotrimoxazole, $25 \mu \mathrm{g}$; nitrofurantoin, $100 \mu \mathrm{g}$ ) used were aseptically placed on plates seeded with isolates adjusted to 0.5 Mac Farlands standard. After incubating for 18-24 hours, the zones of inhibition were interpreted as Resistance (R), Intermediate (I) and Susceptible (S) according to the criteria recommended by the Clinical and Laboratory Standards Institute (CLSI, 2012). The Multiple Antibiotics Resistance (MAR) index and 
$\%$ MAR were calculated for each isolate (Krumperman, 1983).

\section{STATISTICAL ANALYSIS}

The statistical tests were performed using the Prism computer software programme version 5.00 (GraphPad Software, San Diego, CA). Significant limits were set at $\mathrm{P}<0.05$ confidence interval level.

\section{RESULT}

The physicochemical properties of the freshly collected water samples are shown in table 1 . The $\mathrm{pH}$ was observed to increase down the treatment line (A-J) and the final effluent $(J, 7.58)$ was found to be within the Federal Environmental Protection Agency (FEPA) [now known as Federal Ministry of Environment (FME)] and World Health Organization (WHO) acceptable limit of 6.5-8.5. The conductivity decreased down the treatment line with sample A having a value of $1450 \mathrm{~s} \mathrm{~cm}^{-1}$ and $\mathrm{J}$, a value of $350 \mathrm{~s} \mathrm{~cm}^{-1}$. Total dissolved solid decreased down the treatment line with A having the highest value of $720 \mathrm{ppm}$ and J with the lowest at $170 \mathrm{ppm}$. The final effluent $(J)$ was within acceptable limits. Total suspended solids and total solids also decreased down the treatment line with sample A having the highest value of $256 \mathrm{ppm}$ and $976 \mathrm{ppm}$ respectively and sample J with lowest of $14 \mathrm{ppm}$ and 184 ppm respectively. Both parameters, at the point of discharge $(J)$ to the environment met the required standards. Nitrate and phosphate decreased down the treatment line with sample A having the highest value of $97.72 \mathrm{ppm}$ and 213.5 ppm respectively and J with the lowest at 22.11 ppm and $5.87 \mathrm{ppm}$ respectively. However, the final effluent $(J)$ were slightly higher than the required standards (i.e., $2.11 \mathrm{ppm}$ and $0.87 \mathrm{ppm}$ more for nitrate and phosphate respectively). Biological Oxygen Demand (BOD) was within acceptable limit at point of discharge (J). Point A had the highest record of $84.14 \mathrm{ppm}$ and point $\mathrm{J}$ had the lowest value of $3.00 \mathrm{ppm}$. Chemical Oxygen Demand (COD) had the highest value of 38.24 ppm at the influent point (A) and the lowest value of $2.00 \mathrm{ppm}$ at point $\mathrm{D}$ and $\mathrm{E}$ respectively. The final effluent $(J)$ met the required standard. The Dissolved Oxygen (DO) had the highest value $(22.07 \mathrm{ppm})$ at point J, while it was not detected in sample A. The DO was more than the minimum required standard at the point of discharge (J). Total hardness was highest with sample $G$ at a record of $10.00 \mathrm{ppm}$ and lowest in sample J with $7.20 \mathrm{ppm}$. At the point of discharge (J), total hardness was within acceptable limit. Total alkalinity was highest in sample $G$ having a value of $10.00 \mathrm{ppm} \mathrm{CaCO}_{3}$ and lowest with sample B having a value of $6.96 \mathrm{ppm} \mathrm{CaCO}_{3}$. This parameter was within acceptable limit at point of discharge (J). Sulphate was detected at a level of $3.02 \mathrm{ppm}$ in sample $\mathrm{A}$ and absent in the rest of the samples. The heavy metals analyzed were found to be within the FEPA recommended limits at the point of discharge of the effluent (Table 2). Between the influent and final effluent, there was a reduction of iron $(53 \%)$, cobalt $(63 \%)$, copper $(75 \%)$, zinc $(50 \%)$, lead $(92 \%)$, nickel $(60 \%)$ and chromium $(90 \%)$. 
Table 1: Physicochemical analysis of different treatment points (A-J) of a Wastewater treatment plant

\begin{tabular}{lllllllllllll}
\hline Parameters & & \multicolumn{9}{c}{ Sampling Points } & \multicolumn{3}{c}{ Limits } \\
& $\mathrm{A}$ & $\mathrm{B}$ & $\mathrm{C}$ & $\mathrm{D}$ & $\mathrm{E}$ & $\mathrm{F}$ & $\mathrm{G}$ & $\mathrm{H}$ & $\mathrm{I}$ & $\mathrm{J}$ & FEPA & WHO \\
\hline pH & 6.98 & 6.95 & 7.07 & 7.12 & 7.27 & 7.21 & 8.08 & 7.78 & 7.62 & 7.58 & $6.5-8.5$ & $6.5-8.5$ \\
Cond. & 1450 & 1060 & 1050 & 1070 & 1080 & 1060 & 640 & 920 & 960 & 350 & NS & NS \\
TDS & 720 & 530 & 520 & 530 & 520 & 480 & 350 & 300 & 234 & 170 & -50 & 50 \\
TSS & 256 & 110 & 96 & 30 & 20 & 20 & 20 & 18 & 16 & 14 & $\leqslant 30$ & NIL \\
TS & 976 & 640 & 616 & 560 & 540 & 500 & 376 & 318 & 250 & 184 & NS & \\
Nitrate & 97.72 & 91.47 & 70.06 & 73.63 & 91.92 & 46.98 & 26.84 & 106.17 & 21.12 & 22.11 & $\leqslant 20$ & \\
Phosphate & 213.5 & 133.78 & 121.62 & 114.32 & 112.97 & 57.87 & 30.40 & 44.53 & 48.80 & 5.87 & $\leqslant 5$ \\
BOD & 84.14 & 69.88 & 60.85 & 4.82 & 5.43 & 4.00 & 3.80 & 3.90 & 3.50 & 3.00 & $\leqslant 30$ \\
COD & 38.24 & 20.00 & 4.00 & 2.00 & 2.00 & 10.00 & 20.10 & 15.00 & 18.05 & 20.00 & $\leqslant 80$ \\
DO & ND & ND & 0.12 & 0.41 & 3.89 & 9.64 & 13.82 & 16.26 & 18.87 & 22.07 & & \\
TH & 7.6 & 8.4 & 8.0 & 8.2 & 8.4 & 11.2 & 10.0 & 10.8 & 10.0 & 7.2 & NS & \\
TA & 7.52 & 6.96 & 7.52 & 8.00 & 8.00 & 7.84 & 10.00 & 9.76 & 9.12 & 8.88 & NS \\
Sulphate & 3.02 & ND & ND & ND & ND & ND & ND & ND & ND & ND & $\leqslant 500$ & ND \\
\hline
\end{tabular}

Cond., Conductivity ( $\mathrm{s} \mathrm{cm}^{-1}$ ); TDS, Total Dissolve Solids (ppm); TSS, Total Suspended Solid (ppm); TS, Total Solids (ppm); BOD, Biochemical Oxygen demand (ppm); COD, Chemical Oxygen demand (ppm); TH, Total Hardness (ppm); TA, Total Alkalinity (ppm $\mathrm{CaCO}_{3}$ ); ND, Not Detected; DO, Dissolved Oxygen (ppm); Nitrate (ppm); Phosphate (ppm); NS, Not Stated; FEPA, Federal Environmental Protection Agency (1991); WHO, World Health Organization (2005a,b).

Table 2: Heavy metals analyzed at various treatment points of a wastewater treatment plant

\begin{tabular}{llll}
\hline Metals & $\begin{array}{l}\text { Sample A (Influent) } \\
(\mathrm{ppm})\end{array}$ & $\begin{array}{l}\text { Sample J (Effluent) } \\
(\mathrm{ppm})\end{array}$ & $\begin{array}{l}\text { FEPA Limit } \\
(\mathrm{ppm})\end{array}$ \\
\hline Iron & 10.87 & 6.17 & $<20$ \\
Cobalt & 0.86 & 0.30 & $<1$ \\
Copper & 6.06 & 0.90 & $<1$ \\
Zinc & 0.82 & 0.41 & $<1$ \\
Lead & 0.01 & $<1$ \\
Cadmium & 0.18 & $\mathrm{ND}$ & $<1$ \\
Nickel & $\mathrm{ND}$ & 0.13 & $<1$ \\
Chromium & 0.31 & 0.01 & $<1$ \\
Silver & 0.09 & 0.01 & $<1$ \\
\hline
\end{tabular}

FEPA, Federal Environmental Protection Agency (1991); ND, Not Detected; ppm, Parts per million.

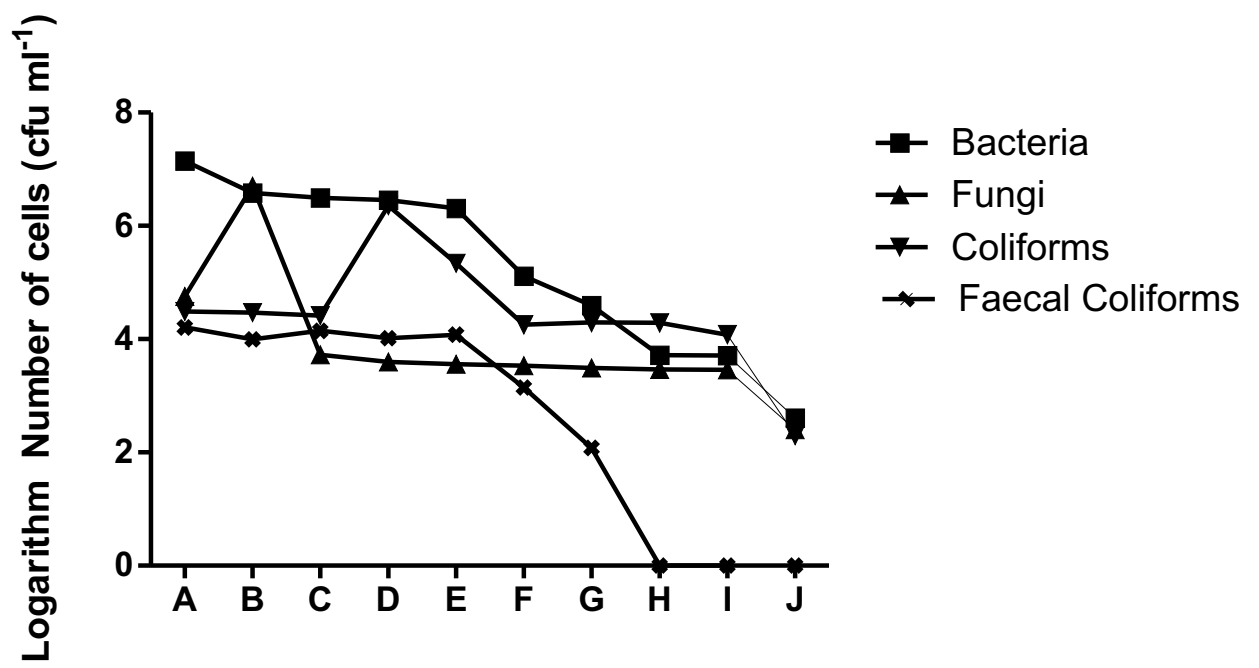

Wastewater Sampling Points

Figure 1: Microbial analysis of water samples (A-J) from a wastewater treatment plant.

The acceptable level of faecal coliforms in effluents of treated wastewater used in agriculture is $\leqslant$ 1000/100 ml (Blumenthal et al., 2000). 
Table 3: The most probable number of coliforms from a wastewater treatment plant

\begin{tabular}{lcc}
\hline Sample points & $\begin{array}{l}\text { Number of changes observed in } \\
\text { positive tubes of } 0.1 \mathrm{ml}, 1 \mathrm{ml} \text { and } 10 \mathrm{ml}\end{array}$ & *Value from 5 tube MPN Table \\
\hline A & 555 & $\geqslant 600$ \\
B & 554 & 1600 \\
C & 544 & 350 \\
D & 544 & 350 \\
E & 542 & 220 \\
F & 541 & 170 \\
G & 531 & 110 \\
H & 431 & 33 \\
I & 411 & 21 \\
J & 410 & 017 \\
\hline
\end{tabular}

*, American Public Health Association (APHA, 1992)

The microbial analyses showed that the population densities decreased down the treatment line (Figure 1) and was within the acceptable faecal coliform effluent levels of $\leqslant$ $1000 / 100 \mathrm{ml}$ of treated wastewater used in agriculture (Blumenthal et al., 2000). The total heterotrophic bacteria count in the influent (A) and effluent $(\mathrm{J})$ wastewater from the treatment plant ranged from $1.4 \times 10^{7} \mathrm{cfu} \mathrm{ml}^{-1}$ to $4.0 \times 10^{2} \mathrm{cfu}$ $\mathrm{ml}^{-1}$ respectively. The fungi count, coliforms and feacal coliforms were $5.6 \times 10^{4} \mathrm{cfu} \mathrm{ml}^{-1}-2.5 \times 10^{2}$ $\mathrm{cfu} \mathrm{ml}^{-1}, 3.2 \times 10^{4} \mathrm{cfu} \mathrm{ml}^{-1}-2.0 \times 10^{2} \mathrm{cfu} \mathrm{ml}^{-1}$ and 1.6 x $10^{4} \mathrm{cfu} \mathrm{ml}^{-1}-0.0 \times 10^{0} \mathrm{cfu} \mathrm{ml}^{-1}$ at the points of entry (A) and discharge (J) respectively. Statistical analysis of variance $(\mathrm{P}<0.05)$ showed significant differences in the values of both the influent and effluents of bacteria, fungi, coliforms and faecal coliforms. The most probable number (MPN) for the presumptive total coliform count of the water samples ranged from $1600 \mathrm{MPN} / 100 \mathrm{ml}$ in sample A to $017 \mathrm{MPN} / 100 \mathrm{ml}$ in sample J (Table 3).

The bacterial colonies that developed on the MacConkey Agar and Eosin Methylene Blue Agar plates were identified as Enterobacter cloacae, Enterobacter amnigenus, Enterobacter cancerogenus, Rabnella aquatilis, Edwardsiella tarda, Klebsiella pneumoniae subsp rbinosderomatis, Escherichia coli strain
1, Butttiauxella ferragutiae, Enteric group 69, Escherichia coli strain 2, Klebsiella oxytoca strain 1, Escherichia albertii and Klebsiella oxytoca strain 2 . The distribution of the coliforms at different sampling points along the treatment line is shown in table 4 . At sampling point $F$, all the coliforms had disappeared except for Butttiauxella ferragutiae and Klebsiella oxytoca strain 1 that persisted in the effluent to be discharged.

The antibiotic sensitivity test of the isolates in table 5 showed that Enterobacter cloacae was resistant to gentamicin (GEN), cotrimoxazole (COT), streptomycin (STR), tetracycline (TET) and nitrofurantoin (NIT). Rabnella aquatilis, Edwardsiella tarda, Escherichia coli, Buttiauxella ferragutiae, were resistant to GEN, COT and TET, while Enterobacter amnigenus was resistant to GEN, COT, STR and TET. Escherichia coli strain 2 was resistant to COT and NIT. Klebsiella oxytoca and Klebsiella oxytoca strain 2 were resistant to GEN and TET and Enterobacter cancerogenus was resistant to GEN, COT and TET. None of the isolates had a $100 \%$ susceptibility to the antibiotics investigated, while all the isolates were resistant to tetracycline. The most prevalent multiple antibiotic resistance phenotype observed among the isolates was TET, GEN, COT. The MAR values ranged from 0.16 to 0.83 and $92 \%$ of the isolates had MAR $>0.2$. 
Table 4: Distribution of isolates along a wastewater treatment line

\begin{tabular}{|c|c|c|c|c|c|c|c|c|c|c|}
\hline \multirow[t]{2}{*}{ Isolates } & \multicolumn{10}{|c|}{ Sampling Points } \\
\hline & A & $\mathrm{B}$ & $\mathrm{C}$ & $\mathrm{D}$ & $\mathrm{E}$ & $\mathrm{F}$ & G & $\mathrm{H}$ & I & $\mathrm{J}$ \\
\hline Enterobacter cloacae & + & + & + & + & + & - & - & - & - & - \\
\hline Enterobacter amnigenus & + & + & + & + & + & - & - & - & - & - \\
\hline Enterobacter cancerogenus & + & + & + & + & + & - & - & - & - & - \\
\hline Rabnella aquatilis & + & + & + & + & + & - & - & - & - & - \\
\hline Edwardsiella tarda & + & + & + & + & + & - & - & - & - & - \\
\hline Klebsiella pneumoniae subsp. rbinosderomatis & + & + & + & + & + & - & - & - & - & - \\
\hline Eschericbia coli strain1 & + & + & + & + & + & - & - & - & - & - \\
\hline Butttiauxella ferragutiae & + & + & + & + & + & + & + & + & + & + \\
\hline Enteric group 69 & + & + & + & + & + & - & - & - & - & - \\
\hline Escherichia coli strain 2 & + & + & + & + & + & - & - & - & - & - \\
\hline Klebsiella oxytoca strain 1 & + & + & + & + & + & - & - & - & - & - \\
\hline Escherichia albertii & + & + & + & + & + & + & + & + & + & + \\
\hline Klebsiella oxytoca strain 2 & + & + & + & + & + & - & - & - & - & - \\
\hline
\end{tabular}

+, Present; -, Not found

Table 5: Antibiotics sensitivity test of bacteria

\begin{tabular}{|c|c|c|c|c|c|c|c|c|}
\hline \multirow[t]{2}{*}{ Isolates } & \multicolumn{8}{|c|}{ Antibiotics $(\mu \mathrm{g} / \mathrm{ml})$} \\
\hline & $\begin{array}{l}\text { NAL } \\
R \leqslant 13 \\
I=14-18 \\
S \geqslant 19\end{array}$ & $\begin{array}{l}\text { GEN } \\
R \leqslant 12 \\
I=13-14 \\
S \geqslant 18\end{array}$ & $\begin{array}{l}\text { COT } \\
R \leqslant 10 \\
I=11-15 \\
S \geqslant 16\end{array}$ & $\begin{array}{l}\text { TET } \\
R \leqslant 14 \\
I=15-18 \\
S \geqslant 19\end{array}$ & $\begin{array}{l}\text { STR } \\
R \leqslant 11 \\
I=12-14 \\
S \geqslant 15\end{array}$ & $\begin{array}{l}\text { NIT } \\
R \leqslant 11 \\
S \geqslant 11\end{array}$ & $\begin{array}{l}\text { MAR } \\
\text { Index }\end{array}$ & RESISTANT PHENOTYPE \\
\hline Enterobacter cloaca & $42(\mathrm{~S})$ & $0(\mathrm{R})$ & $0(\mathrm{R})$ & $0(\mathrm{R})$ & $0(\mathrm{~S})$ & $0(\mathrm{~S})$ & 0.83 & GEN, COT, TET \\
\hline Enterobacter amnigenus & 14(R) & $10(\mathrm{R})$ & $0(\mathrm{R})$ & $0(\mathrm{R})$ & $8(\mathrm{R})$ & $16(\mathrm{~S})$ & 0.83 & NAL, GEN, COT, TET, STR \\
\hline Enterobacter cancerogenus & $20(\mathrm{~S})$ & 13(R) & $0(\mathrm{R})$ & 14(R) & $18(\mathrm{~S})$ & $18(\mathrm{~S})$ & 0.50 & GEN, COT, TET \\
\hline Rabnella aquatilis & $20(\mathrm{~S})$ & $12(\mathrm{R})$ & $0(\mathrm{R})$ & $13(\mathrm{R})$ & $20(\mathrm{~S})$ & $20(\mathrm{~S})$ & 0.50 & GEN, COT, TET \\
\hline Klebsiella pneuminiae & $20(\mathrm{~S})$ & $12(\mathrm{R})$ & $18(\mathrm{~S})$ & $0(\mathrm{R})$ & 14(R) & $18(\mathrm{~S})$ & 0.50 & GEN, TET, STR \\
\hline Escherichia coli strain 1 & $20(\mathrm{~S})$ & $10(\mathrm{R})$ & $0(\mathrm{R})$ & $0(\mathrm{R})$ & 14(R) & $18(\mathrm{~S})$ & 0.66 & GEN, COT, TET, STR \\
\hline Buttianxella ferraguitiae & $0(\mathrm{R})$ & $12(\mathrm{R})$ & $9(\mathrm{R})$ & $0(\mathrm{R})$ & $12(\mathrm{R})$ & $17(\mathrm{~S})$ & 0.83 & NAL, GEN, COT, TET, STR \\
\hline Enteric group 69 & $25(\mathrm{~S})$ & $19(\mathrm{~S})$ & $25(\mathrm{~S})$ & $0(\mathrm{R})$ & $15(\mathrm{~S})$ & $20(\mathrm{~S})$ & 0.16 & TET \\
\hline Escherichia coli strain 2 & $20(S)$ & $16(S)$ & $0(\mathrm{R})$ & $0(\mathrm{R})$ & $20(\mathrm{~S})$ & $10(\mathrm{R})$ & 0.20 & COT, TET, NIT \\
\hline Klebsiella oxytoca strain 1 & $20(\mathrm{~S})$ & $10(\mathrm{R})$ & 18(S) & $0(\mathrm{R})$ & $15(\mathrm{~S})$ & $17(\mathrm{~S})$ & 0.33 & GEN, TET \\
\hline Escherichia albertii & $20(S)$ & $15(\mathrm{R})$ & $25(\mathrm{~S})$ & $10(\mathrm{R})$ & $20(\mathrm{~S})$ & $15(\mathrm{~S})$ & 0.33 & GEN, TET \\
\hline Klebsiella oxytoca strain 2 & 16(R) & $9(\mathrm{R})$ & $16(S)$ & $0(\mathrm{R})$ & $12(\mathrm{R})$ & $13(\mathrm{~S})$ & 0.66 & NAL, GEN, TET, STR \\
\hline Edwardsiella tarda & $40(\mathrm{~S})$ & $0(\mathrm{R})$ & $0(\mathrm{R})$ & $0(\mathrm{R})$ & $14(\mathrm{R})$ & $0(\mathrm{R})$ & 0.83 & GEN, COT, TET, STR, NIT \\
\hline
\end{tabular}

S, Susceptible; R, Resistant; I, Intermediate; MAR Index, Multiple Antibiotics Resistance index; NAL, nalidixic acid $\left(30 \mu \mathrm{g} \mathrm{ml}^{-1}\right)$; GEN, gentamicin $\left(10 \mu \mathrm{g} \mathrm{ml}^{-1}\right)$; COT, cotrimoxazole $\left(25 \mu \mathrm{g} \mathrm{ml}^{-1}\right)$; TET, Tetracycline $\left(30 \mu \mathrm{g} \mathrm{ml}^{-1}\right)$; STR, streptomycin $\left(10 \mu \mathrm{g} \mathrm{ml}^{-1}\right)$; NIT, nitrofurantoin $\left(100 \mu \mathrm{g} \mathrm{ml}^{-1}\right)$; *, Clinical and Laboratory Standards Institute (CLSI, 2012).

\section{DISCUSSION}

The physicochemical and coliform result of the treated sewage effluent samples, when compared to the raw sewage samples revealed improved sewage quality. Sewage treatment using modern highly efficient compact system comprising aerobic processes, improve sewage quality and reduces its toxicity so that discharge to the environment will not pose any serious threat (Jowett, 1997). The $\mathrm{pH}$ of the sewage plant agrees with an earlier investigation of the same treatment plant by Longe and Ogundipe (2010) which varied between 7.1 and 9.0. According to van der Gast and Thompson (2005), microorganisms in wastewater treatment systems can grow over a wide range of $\mathrm{pH}$ (6 to 9$)$ and the microbial community compositions are also remarkably affected by $\mathrm{pH}$ variation (Gao et al., 2016). Similar results for TDS was obtained by Asia and Akporhonoe (2007) and Adeniran et al. (2012). The low levels of BOD and total suspended solids (TSS) were similar to earlier investigations by Adeniran et al. (2012). The higher the BOD value, the greater the pollution hazards (Beychok, 1971) and a TSS level of $80 \mathrm{mg} / \mathrm{L}$ results in adverse effect on macro invertebrates (Garie and McIntoch, 1986). The final effluent had a dissolved oxygen of $22.07 \mathrm{mg} / \mathrm{L}$. The improvement noticed in the DO along the treatment line may be due to the reduction in organic matter contamination and simultaneous mixing of atmospheric oxygen (Prasad et al., 
2006). Also, the presence of free oxygen in water is an indication of the ability of that water to support life. Ademoroti, (1996) noted that healthy body of water should have a DO of at least 5.2 $\mathrm{mg} / \mathrm{L}$.

The removal efficiency for nitrate and phosphate stand at $78 \%$ and $97 \%$ respectively. Despite their reduction, the level of nitrate and phosphate in the final effluent exceeds the permissible FEPA limit. This calls for concern as discharge of effluent with high levels of nitrate and phosphate into water bodies leads to eutrophication (Rockström et al., 2009). A 100\% removal of sulphate was observed from influent $(3.02 \mathrm{mg} / \mathrm{l})$ to effluent (not detected). The wastewater treatment plant was quite efficient in removal of sulphate. Although sulphate is classified as nontoxic, intake of water containing sulphate can lead to diarrhoea. Presence of sulphate in domestic water may be due to addition of detergents waste from washing (Sharma and Dubey, 2011).

The treatment plant was effective in the remediation of the analyzed heavy metals. The high difference in concentration of iron between influent and effluent might be due to its utilization by microorganism in metabolism. Presence of high concentrations of toxic heavy metals in wastewater directly leads to both contamination of receiving water bodies and deleterious impact on aquatic life (Moten and Rehman, 1998). Overall, the physicochemical results showed the high purification efficacy of the wastewater treatment plant.

The microbial analyses showed that the treatment plant was effective in reducing the microbial load of the wastewater and the results conformed to the acceptable faecal coliform effluent levels of $\leqslant$ $1000 / 100 \mathrm{ml}$ of treated wastewater used in agriculture (Blumenthal et al., 2000). Inefficient treatment processes result in microorganisms being released with treated effluents in the aquatic environment (George et al., 2002). These contaminated effluents pose a health risk to humans and animals upon exposure to contaminated water.

There was a great reduction in the number of pathogens and multiple antibiotic-resistant bacteria that was discharged in the effluent water after treatment. The presence of antibioticresistant bacteria is of major concern in wastewater treatment plant, for it could serve as a source of dissemination of antibiotic resistance to the community and pose a potential threat to human and animal health as it gets into the food chain. Bacterial resistance to antibiotics and other antimicrobial agents pose increasing problem to the treatment of different infectious diseases (Samanta et al., 2012). Antibiotic resistance is also an economic burden on the healthcare system. Resistant infections not only cost more to treat, but also can prolong healthcare use (Frieden, 2010).

This study has shown the effectiveness of a wastewater treatment plant in the reduction of heavy metals, nitrate, phosphate, organic matter and pathogenic organisms that are present in wastewater discharged into the environment. The reductions in the concentrations of these parameters in treated wastewater will reduce environmental pollutions that may result in eutrophication of water bodies and the spread of pathogenic organisms in the environment. Although, there is also the possibility of discharge of antimicrobial-resistant organisms through sewage into the environment from treated wastewater processes.

\section{ACKNOWLEDGMENT}

We thank the Director of Works and Physical Planning, University of Lagos, Lagos, Nigeria for giving us permission to carry out this study at the University of Lagos wastewater treatment plant.

\section{REFERENCES}

Ademoroti, C.M.A. 1996. Environmental Chemistry and Toxicology. Foludex Press Ltd., Ibadan, Nigeria, pp. 134-146.

Adeniran, A.E., Aina, A.T., Oshunrinade, O.O. and Oyelowo, M.A. 2012. Assessment of The Efficiency of constructed wetland in domestic waste water treatment at the University of Lagos Nigeria. J. Sust. Dev. Environ. Prot. 2, 21-28.

Akpata, T.V.I and Ekundayo, J.A. 1998. Fecal Pollution of the Lagos Lagoon. Nig. J. Sci. 12, 44-51.

American Public Health Association (APHA) 
1985. Standard Methods for the Examination of Water and Wastewaters, 19th Edition. Am. Public Health Assoc., Wash. DC. 1666pp.

APHA 1992. Standard Methods for the Examination of Water and Wastewater. In: American Public Health Association (APHA), American Water Works Association (AWWA) and Water Pollution Control Federation (WPCF), 18th edition. Washington, D.C.

Asano T. and Levine A. 1996. Wastewater reclamation, recycling and reuse: Past, present and future. Water Sci. Tech. 33, 1011.

Asia, I.O. and Akporhonor, E.E. 2007. Characterization and physicochemical treatment of wastewater from rubber processing factory. Int. J. Phy. Sci. 2, 061067.

Badejo, A.A., Coker A.O. and Sridhar, M.K.C. 2011. Tertiary hospital wastewater treatment using reed bed technology planted with Vetiveria nigritana benth and Phragmites karka retz. Proceedings of the Environmental Management Conference, Federal University of Agriculture, Abeokuta, Nigeria, pp. 497

Beychok, M.R. 1971. Performance of surfaceaerated basins. Chem. Engng. Prog. Symp. Ser. 67, 322-339.

Blumenthal, U.J., Mara, D.D., Peasey, A., RuizPalacios, G. and Stott, R. 2000. Guidelines for the microbiological quality of treated wastewater used in agriculture: recommendations for revising $W H O$ guidelines. Environment and Health Bulletin of the World Health Organization, 78(9).

Burkhardt, W. and Calci, K.R. 2000. Selective accumulation may account for shellfishassociated viral illness. Appl. Environ. Microbiol. 66, 1375-1378.

Chen, Y., Lan, S., Wang, L., Dong, S., Zhou, H., Tan, Z. and Li, X. 2017. A review: Driving factors and regulation strategies of microbial community structure and dynamics in wastewater treatment systems. Chemosphere 10, 1016.

Clinical and Laboratory Standards Institute (CLSI). 2012. Performance standards for antimicrobial susceptibility testing; TwentySecond Informational Supplement 32(3),
M100-S22.

Collee, J.G., Duguash, R.L., A.G.G. and Marimon, B.P. 1989. Mackie and McCartney Practical Microbiology (13 ${ }^{\text {th }}$ edition). Churchill Livingstone, pp. 234-238.

Fakayode, S.O. 2005. Impact Assessment of Industrial effluent on water quality of the receiving Alaro River in Ibadan, Nigeria. Ajeam-Ragee 10, 1-13.

Federal Environmental Protection Agency (FEPA), (1991). National Environmental Protection Regulations (Effluent Limitation) Regulations. S.1.8, Federal Republic of Nigeria Official Gazette, Lagos, 78pp.

Frieden, T.R. 2010. Antibiotic Resistance and the Threat to Public Health. U.S. Department of Health and Human Services (HHS). http://www.hhs.gov/asl/testify/2010/0 4/t20100428b.html Accessed March 10, 2016.

Gao, P., Xu, W.L., Sontag, P., Li, X., Xue, G., Liu, T. and Sun, W.M. 2016. Correlating microbial community compositions with environmental factors in activated sludge from four full-scale municipal wastewater treatment plants in Shanghai, China. Appl. Microbiol. Biotech. 100, 4663-4673.

Garie, H.L., McIntosh, A. 1986. Distribution of benthic macroinvertebrates in a stream exposed to urban runoff. J. Am. Water Resour. Assoc., 22(3), 447-455.

George, I., Crop, P. and Servais, P. 2002. Fecal coliform removal in wastewater treatment plants studied by plate counts and enzymatic methods. Water Res. 36, 2607-2617.

Jowett, E.C. 1997. Sewage and leachate wastewater treatment using the absorbent Waterloo biofilter. Site Characterization and Design of On-Site Septic Systems, ASTM Spec. Tech. Publ., STP 1324: 261-281.

Krumperman, P.H. 1983. Multiple antibiotic resistance (MAR) indexing of E. coli to identify high risk sources of fecal contamination of foods. Appl. Environ. Microbiol. 46, 165-170.

Lens, P., Zeeman, G. and Lettinga, G. 2001. Decentralised sanitation and reuse; concept systems and implementation. London, IWA Publishing. 
Longe, E.O. and Ogundipe, A.O. 2010. Assessment of Wastewater Discharge Impact from a Sewage Treatment Plant on Lagoon Water, Lagos, Nigeria. Res. J. Appl. Sci. Eng. Technol.2, 274-282.

Moten, A.M. and Rehman, A. 1998. Study on heavy trace metal ions in industrial waste effluents in Pakistan. Enviromentalexpert.com, article-909

Olutiola, P.O., Awojobi, K.O., Oyedeji, O., Ayansina, A.D.V. and Cole O.O. 2010. Relationship between Bacterial Density and Chemical Composition of a Tropical Sewage Oxidation Pond. Afr. J. Environ. Sci. Technol. 49, 595-602.

Osibanjo, O. Daso A.P. and Gbadebo A.M. 2011. The impact of industries on surface water quality of River Ona and River Alaro in Oluyole Industrial Estate, Ibadan, Nigeria. Afr.J. Biotech. 10, 696-702.

Prasad, G., Rajeev, R. and Chopra, A.K. 2006. Sand intermittent Technology for safer domestic sewage treatment. J. Appl. Sci. Environ. Manage. 10, 73-77.

Raschid-Sally, L. and Jayakody, P. 2008. P. Drivers and characteristics of wastewater agriculture in developing Countries: Results from a global assessment, Colombo, Sri Lanka. IWMI Research Report 127, International Water Management Institute, Colombo, 35pp.

Rockström, J., Falkenmark, M. and Lannerstad, M. 2009. Assessing the water challenge of a new green revolution in developing countries. Proc. Natl. Acad. Sci. 104,
6253-6260.

Samanta, A., Bera, P., Khatun, M., Sinha, C., Pal, P., Lalee, A. and Mandal, A. 2012. An investigation on heavy metal tolerance and antibiotic resistance properties of bacterial strain Bacillus sp. isolated from municipal waste. J. Microbiol. Biotech. Res. 2, 178-189.

Sharma, D. and Dubey, A. 2011. Assessment and treatment of municipal wastewater of Indore city of India. Arch. Appl. Sci. Res., 3, 450-461.

van der Gast, C.J. and Thompson, I.P. 2005. Effects of $\mathrm{pH}$ amendment on metal working fluid wastewater biological treatment using a defined bacterial consortium. Biotech. Bioeng. 89, 357-366.

World Health Organization 2005a. Mercury in Drinking-water, Background document for development of WHO Guidelines for Drinking-water Quality, Geneva, World Health Organization Publication WHO/SDE/WSH/05.08/10.

World Health Organization 2005b. Nickel in Drinking-water, Background document for development of WHO Guidelines for Drinking-water Quality, Geneva, World Health Organization Publication WHO/SDE/WSH/05.08/55.

Zhou, H. and Smith, D.W. 2002. Advanced Technologies in Water and Wastewater Treatment. J. Environ. Eng. Sci.1, 247-264. 